$10(1)(2021) 1-11$
Unnes Science Education Journal
Accredited Sinta 3

\title{
Learning Biology for Sustainable Development Using Hands-On Strategy: Can Gender Achievement Gap Reduce?
}

\author{
Peter Abayomi Onanuga ${ }^{\bowtie}$, Adewale Owodunni Saka, Rita Pelumi Ogwokhademhe
}

DOI: http://dx.doi.org/10.15294/usej.v10i1.42747

Department of Science and Technology Education, Olabisi Onabanjo University, Ago-Iwoye, Nigeria

\section{Article Info}

Submitted 20 November 2020 Revised 11 December 2020 Accepted 4 February 2021

\section{Keywords}

Hands-on, gender, students' achievement, sustainable development

\begin{abstract}
Despite the importance of biology for sustainable development, students' performance in the subject has been inconsistent. Several interventions have been used to improve students' learning of Biology but the inconsistency in performance persists. Thus, this study investigated the use of hands-on learning in enhancing students' academic achievement. The research adopted a pretest-posttest control group quasi-experimental research design with $2 \times 2$ factorial. The study also examined the moderating effect of gender on academic achievement. Fifty-eight students offering Biology in the intact classes of two randomly selected schools participated in the study. The data was collected using a 25-item Biology Achievement Test for Students (BATS) subjected to face and content validities, and reliability test. The test-retest reliability method yielded a reliability coefficient of 0.68 . The data analyses revealed a significant difference in the effect of strategy on the academic achievement of students in Biology $(F(1,53)=8.595), p=0.05$, but in favour of the conventional method of teaching. Further findings showed no significant difference in the effect of gender on the academic achievement of students $(F(1,53)=0.980), p>0.05$. The researchers noted that hand-on activities are important for Biology learning and recommended that school authorities should allocate adequate time for that purpose.
\end{abstract}

\section{How to Cite}

Onanuga, P. A., Saka, A. O., \& Ogwokhademhe, R. P. (2021). Learning Biology for Sustainable Development Using Hands-On Strategy: Can Gender Achievement Gap Reduce?. Unnes Science Education Journal, 10(1), 1-11.

Correspondence Author:

E-mail: pierrenuga@gmail.com 


\section{INTRODUCTION}

Global competitiveness of a nation in the emerging economy depends on its scientific and technological development. Knowledge of science is crucial for the survival of humanity in a society powered by technology. Thus, learning of science is being promoted at every tier of education. Biology is an aspect of science in the senior school curriculum in Nigeria listed under Science and Mathematics field of study with other subjects such as Chemistry, Physics, Further Mathematics, Health Education, Agriculture, Physical Education and Computer Studies (Federal Republic of Nigeria [FRN], 2014). The implication is that students are at liberty to pick two, three or four from the subjects in this category, based on their potential, interest and capability. Thus, Biology is an optional subject in Nigerian secondary school curriculum.

Biology is the study of human composition in terms of structure, functions and development (Okoye, 2016). Biology equips learners with the skill to peacefully cohabit with other members of society (Mwanda, Odundo, \& Midigo, 2017). Odewumi, Akintola and Bello (2020) viewed it as a prerequisite for many special courses such as Medicine, Pharmacy, Botany, Zoology, Anatomy and Microbiology. Biology connects science with technology to transform society for the comfort of humanity in their daily activities and their survival. Biology is also prime in the achievement of sustainable development goals. Biology is at the heart of the understanding of some disciplines (e.g., Medicine, Biochemistry, Agriculture) to achieve some of the sustainable development goals (SDGs). For instance, the sustainable development agenda targets promotion of healthy living and well-being of individuals across all ages. It is also to ensure the security of the society, termination of hunger and sustainable agriculture (Rosa, 2017). These goals and others may be difficult to achieve without the applications of biology and its concepts.

Similarly, Wibowo and Sadikin (2019) maintained that Biology and other science subjects could reduce the problems of climate change and other prominent factors for sustainability in soil remediation, clean water, quality education and affordable energy. Hence, the developmental sustainability of a nation requires paying adequate attention to Biology education. In recognition of the need for advancement in science and technology for national prosperity, FRN (2014) through the National Policy on Education stated that government would provide adequate funds for science and technology education at the secondary level of education. The policy also targeted reasonable allocation of the government on university education to science and technology. It means that the country puts a high premium on the development of its science and technology education.

On one hand, the fluctuating performance of students in external examination pointed out that past efforts are not yielding the desired results. The mean performance of students in the subject reduced from 29 in 2014 to 25 in 2015. In 2016, the mean performance rose to 31 and remained as such in 2017. The mean performance however reduced to 30 in 2018 (The reports of West African Examinations Council (WAEC) Chief Examiners, 2014-2018). WAEC is the body in charge of examinations for the award of certificates in public interest in English-speaking countries in West Africa. The fluctuation in the performance of students in Biology is not the desire of the nation which intends to navigate the world using its science and technology. Other researchers also alluded to the unsatisfactory performance of the students in Biology in Nigeria (Okoye, 2016; Odewumi et al., 2020; Oladimeji \& Adebisi, 2020). The difficulty to learn Biology is not limited to Nigeria. Researchers such as Matawali et al. (2019) in Malaysia, Ong'amo, Ondigi, and Omariba (2017) in Kenya as well as Wai and Khine (2020) in Yangon District in Myanmar also reported the same trend.

On the other hand, the reports of WAEC chief examiners and researchers such as Odewumi et al. (2016); Oladimeji and Adebisi (2020) believed that the use of inappropriate teaching methods contributed to the inconsistency in the performance of students in Biology. The Reports (2014-2018) advocated the use of practical and field works to improve the learning of Biology in secondary schools. It was also suggested that school laboratories should be well equipped to enable exposure of students to hands-on experiences. Exposure of students to practical activities helps them to clarify their doubts on the learning materials because they can connect what they see to what is experienced. However, Enebechi in Oladimeji and Adebisi (2020) observed that secondary school Biology teachers in Nigeria do not always teach practical along with each topic. They wait to receive the instructions on the specimens for the practical examinations before they teach practical works. The delay lends credence to the fact the fluctuations in the performance of students in Biology might be as a result of the use of ineffective teaching methods by the teach- 
ers. The use of defective methods to teach science subjects is not limited to Nigeria.

In his summary of methods of teaching in science, BouJaoude (2011) noted that science education at all levels lacks the thrust to prepare individuals for the technology-driven 21st-century society. The researcher observed that the methods of teaching were ineffective and recommended the use of approach which are suitable to improve the quality of science education. Noting that many teaching methods are teacher-centred, Ziff (n.d) concluded that teachers typically spend $80 \%$ of the time dominating classroom activities whereas, students use only $20 \%$ of the time for active participation in learning. This observation means that any teaching method that does not put the students at the centre of teaching and learning process can no longer meet the learning needs of the students who are from diverse backgrounds. FRN (2014) noted the inadequacies of traditional methods of teaching and stipulated that the teaching-learning processes should be practical, activity-based, experiential and ICTsupported.

Several studies have suggested the use of hands-learning strategy as a form of practical, activity-based and experiential teaching due to its benefits to the students (Aji \& Khan, 2019; Filgona, Sababa \& Filgona, 2016; Sadi \& Cakiroglu, 2011; Taylor, 2019). Hands-on learning strategy entails learning-by-doing and gives students the opportunities to actively participate in the learning process. Unlike the traditional method of teaching that is teacher-focused, the hands-on approach places the students as the centre-piece of the teaching-learning process and thus makes them take control of their learning. The teachers serve as a facilitator to ensure that every learner participates actively without much conflict through provision of necessary support. Hands-on strategy facilitates the application of knowledge acquired in one domain to another situation. It also helps learners to reflect on the acquired knowledge which leads to better understanding. The strategy equips learners with the necessary skills to learn science without frustration and motivate them to choose science and its allied professions (Taylor, 2019). Odewumi et al. (2020) demonstrated that hands-on involved all sense organs and thus improved the cognitive, affective and psychomotor skills of the learners.

Studies on hands-on learning strategy as an intervention in teaching and learning of Biology are in the literature. A work by Ibrahim (2020) examined the effect of guided inquiry as a form of hands-on strategy to improve students' academic performance in Biology at senior secondary school level in Ringim Educational Zone, Jigawa, Nigeria. The findings reported a significant difference in the mean scores of the students exposed to guided inquiry strategy and the lecture method in terms of achievements and retention of knowledge. The higher performance was in favour of students taught with guided inquiry strategy. The research concluded that the guided inquiry strategy enhanced learners' academic performance and aided their knowledge retention in Biology. A similar study by Sukmawati, Setyosari, Sulton, and Purnomo (2019) examined the effect of project-based collaborative learning (PBCL) strategy on the conceptual understanding and application of Biology for students with social skills. The study design was a quasi-experimental design with seventy-five participants. The results indicated that students taught with PBCL recorded a significantly higher mean score in the post-test compared to their counterparts in the control group. However, despite the availability of pre-test scores, Sukmawati et al. used Multivariate Analysis of Variance (MANOVA) which did not take into account the pre-test scores. Ideally, Multivariate Analysis of Covariance (MANCOVA) is the most appropriate to take care of these scores. Also, students in the control group were exposed to another intervention called collaborative learning strategy that involved grouping the students instead of the usual traditional method of teaching. The authors should have included another group with placebo treatment (conventional method). It is therefore difficult to infer causality from the reports of this study.

In a quest to find an alternative method of teaching Biology, Odewumi et al. (2020) investigated the effects of plastic relief sculpture (PRS), a form of hands-on strategy, on senior high school students in Biology practical activities. The findings showed a significant difference between the performance of the students taught with PRS and those exposed to the conventional method. The study concluded that PRS was more effective than the traditional approach to improve students' academic achievement in senior secondary school Biology. Meanwhile, Oladimeji and Adebisi (2020) found that the use of natural specimens is more effective than the use of synthetic learning materials in Biology learning. This result may be due to the originality of the materials compared to the synthetic material. Original material can appeal to different learning styles of the students. The study also found a significant effect of synthetic and natural specimens on the acquisition of science process skill 
by the students. It also improves their application of Biology concepts. The higher mean gain of the students that used natural resources over those that used the synthetic material indicated that students prefer natural resources to learn Biology. These findings further revealed that handson strategies (natural and synthetic specimens) were effective than the conventional method to enhance students' performance in Biology. The conventional approach involved the drawing of learning items on the whiteboard. The conclusion from the study was that both the synthetic and natural specimens were effective to improve the acquisition and application of science process skills by students offering Biology.

In this same vein, Shana and Abulibdeh (2020) determined the effect of practical work on the academic performance of students in Biology and Chemistry secondary schools. The research adopted pretest-posttest control group quasiexperimental research design with participants selected from tenth and eleventh grades in two private schools in Abu Dhabi. The results showed that the students exposed to intensive practical work recorded significantly higher mean achievement score than their counterparts taught with the conventional method. The study concluded that learners should be exposed to practical work to perform better in subjects such as Chemistry and Biology. Surprisingly, the authors discussed the effect of the strategy (or intervention) in terms of correlation despite the use of Analysis of Covariance (ANCOVA) as inferential statistics. Correlation is to determine a relationship between two variables and not to infer causality.

Many scholars are of the view that the gender of the students determines their academic achievement in Biology. Cooper and Barry (2020) reported that gender is a significant predictor of students' achievement in Biology. This finding is contrary to the position of the United Nations Children's Education Fund (2011) that difference in academic performance should not be consequent upon the gender difference. However, female students appear to have fear for the learning of science. The phobia is responsible for the disproportionate number of males and females found in science disciplines (Jegede \& Olu-Ajayi, 2017). They also perform less than their male counterparts in science and technology because of the genetic traits and societal misconception that science is a male-dominated discipline.

Issues of gender difference in academic performance have been at the focal point of research for years with mixed findings. Borgonovi and Greiff (2020) examined the gender gaps in cognitive and attitudinal dimensions of problem-solving. They also determined how gender achievement gaps between the countries related to inequality at the societal level. The study involved 237,115 students from 42 countries that participated in the 2012 round of the Programme for International Students Assessment (PISA). The data analysis revealed that males outperformed females in cognitive dimensions of problem-solving and held more positive attitudes towards problem-solving. The study further reported that the gender gap in performance varied across countries. The male students in nations with higher gender inequality recorded higher mean score compared to their male counterparts in countries with lower gender inequality. These findings mean that, across nations, there exists gender difference in academic performance which depends on societal perception of what constitutes gender disparity. The study, however, did not establish whether or not the mean difference in performance by gender was statistically significant. In a study, Odewumi et al. (2020) found no statistically significant difference in the mean performance of male and female students after exposure to PRS and conventional method. The report was similar to that of Ibrahim (2020) that no significant difference existed in the mean performance of males and females after exposure to the guided inquiry strategy and conventional method.

In the analysis of the enrolment and attainment in the core subjects of Biology, Chemistry and Physics by gender from the Scottish Qualification Authority records from 2008-2018 (for higher and advanced higher level) and 2014 -2018 (for National 5), Adolphus (2020) found a significant difference in the mean performance by gender in all the three subjects at the advanced higher level. Further analyses illustrated gross underrepresentation of girls in physics and that majority of the girls performed better than their male counterparts in science generally. This finding negates the reports of the Organization of Economic Cooperation and Development ([OECD], 2015) that girls tend to underachieve compared to boys in science subjects. The performance difference may be from the populations of the samples selected for the study. Nevertheless, the study of Ogunkola and Bilesanmi-Awoderu (2012) on the effectiveness of laboratory base method found that the gender difference did not determine the achievement of the students in Biology.

The studies reviewed here seem to show that Biology is vital for scientific and technological development of a nation and its roles in 
sustainable development cannot be undervalued. However, over the years, the performance of the students in the subject has been unstable. This inconsistency means that there is a need to ease students' learning of Biology to achieve some sustainable development goals. Meanwhile, the reports of WAEC examiners and other researchers have suggested the use of hands-on learning strategy to teach Biology. The evidence from literature has shown that several studies have been conducted on the effectiveness of the strategy. However, some of the findings were based on faulty experimental design, statistical procedures and analyses. Therefore, this study is necessary to either support or refute the claim on the effectiveness of the strategy. Knowledge in a discipline accumulates in bits through research conducted in the subject area over a long period (Roberts, 2010). Similarly, the review showed that some studies restricted the use of the hands-on learning activities to either the classrooms or the school laboratories and without the use of smartphones technologies. This study, therefore, exposed the learners to out-of-classroom experiences within the school premises to enable them to see things in the natural environment. Also, studies that incorporated the use of smartphone technology to facilitate learning through a hands-on strategy which is not popular in the literature. Also, there are several reports on the gender difference in academic achievement in the literature. The difference contributes to the gender disparity in almost all areas of human lives (Bertocchi \& Bozzano, 2019). The implication is that there is a need for teachers/researchers to evolve teaching methods that can bridge the gap. It is against this background that the study incorporated gender as a moderating variable to determine its main and interaction effect with the strategy on students' achievement in Biology.

This study is needed at this time in Nigeria where the performance of students in Biology is not only poor but has been inconsistent over the years. This is against the backdrop of the need for Biology for attaining sustainable development through science and technology. Besides, equity in education which is one of the promises of the sustainable agenda 2030 may be a mere proposal if one sex continues to dominate other in learning achievement. Hence, gender is part of this study.

The purpose of this study was to determine the effectiveness of strategy (hands-on and conventional method) towards enhancing students' achievement in senior secondary school Biology. Specifically, the study: Determined effect of hands-on learning strategy on senior secondary school students' achievement in secondary Biology; Examined the moderating effect of gender on senior secondary school students' achievement in secondary Biology. Determined the effect of hands-on learning strategy in closing the gender achievement gaps in secondary Biology.

The study was guided by the following hypotheses tested at 0.05

H01: There is no significant difference in the effect of hands-on learning strategy on students' academic achievement in Biology.

H02: There is no significant difference in the effect of gender on students' academic achievement in Biology.

H03: There is no significant interaction effect of strategy and gender on students' academic achievement in Biology.

\section{METHOD}

This study adopted a pre-test post-test control group quasi-experimental research design involving a $2 \times 2$ factorial matrix. The quasiexperimental design allows the establishment of a cause-effect relationship between variables (Sadi \& Cakiroglu, 2011). The two groups were randomly assigned to experimental and control groups. Two levels of the strategy (hands-on learning and conventional method) were also crossed with the two levels of gender (male and female) to examine their interaction effect on students' achievement in Biology.

The design layout is indicated thus:

$\begin{array}{lll}\mathrm{O}_{1} & \mathrm{X}_{\mathrm{H}} & \mathrm{O}_{2} \text { (Experimental group) } \\ \mathrm{O}_{1} & \mathrm{X}_{\mathrm{C}} & \mathrm{O}_{2} \text { (Control group) }\end{array}$

$\mathrm{O}_{1}$ and $\mathrm{O}_{2}$ represent pre-test and post-test observations.

$\mathrm{X}_{\mathrm{H}}$ and $\mathrm{X}_{\mathrm{C}}$ represent the experimental treatment (Hands-on learning strategy) and conventional method (control group) respectively.

The population of the study consisted of all senior secondary one (SS 1) students offering Biology in all the sixteen public senior secondary schools in Ijebu-North Local Government Area of Ogun State, Nigeria. The Local Government Area has two state constituencies: Ijebu North I and Ijebu-North II with corresponding seven (7) and nine (9) public senior secondary schools respectively. Two schools were randomly selected from the local government area such that a school represented each state constituency. This selection was to ensure enough distance from the schools to avoid contamination due to the interaction between the students of the selected schools. A sample of fifty-eight (58) students from two intact classes of SS 1 students offering Biology in the 
selected schools participated in the study. Biology is an optional subject for students in Nigerian secondary schools. Hence, all the students offering Biology in the selected schools participated in the study. The experimental group consisted of the thirty-four students (14 males and 20 females) whereas the control group consisted of twentyfour students (11 males and 13 females).

Using the study of Shana and Abulibdeh (2020) as the foundation, the power analysis from G* power 3.1 calculator (Faul, Erdfelder, Buchner, $\&$ Lang, 2009) revealed that the total sample needed for this study was forty-six (effect size $=0.547$; $\alpha$ err prob $=0.05$; power $(1-\beta$ err prob $=0.95$; numerator $\mathrm{df}=1$; number of groups $=2$; number of covariate $=1$ ). Besides, for comparison by gender in the hands-on group, the analysis revealed that a total sample of 10 was adequate to avoid types 1 and 2 errors.

Two instruments used for the study were Teachers' Instructional Guides and Biology Achievement Test Students (BATS). The researchers prepared two different guides for the study. One instructional guide was for the experimental group and the other for the control group. The instructional guide for the experimental group consisted of the detailed contents of the topics to learn and the related hands-on activities. Similarly, the learning guide for the control group consisted of the same contents but no hands-on activities. The lesson plans were critiqued for validity by two graduate students in Biology Education at the Olabisi Onabanjo University (OOU), Ago-Iwoye, Ogun State, Nigeria and three experienced Biology teachers in secondary schools. The researchers then handed over an appropriate guide to the teacher in each group to ensure strict compliance with the operational guidelines of the study.

The Biology Achievement Test for students (BATS) was developed by the researchers to collect data on students' achievement in Biology. It consisted of twenty-five (25) multiple-choice test items. Examples are: 1. A ---------- is a natural resource like Uranium or coal that is not replaced as it is used. A. non renewable resources B. radoiactive C. renewable resources D. fossil fuel. 2 . The term used in describing the effective management of natural resources is A. preservation B. utilization C. development D. conservation. 3 . The major polutanat around airport residential area is noise D. protected A. oil spillage B. soil C.

The choice of this test mode was due to its non-subjectivity and consistency. The items in the test were selected from past WAEC ques- tion papers in the areas of conservation of natural resources, benefits of natural resources and pollution. These topics were those listed in the curriculum for coverage during the term to avoid disruption of the school calendar and activities. The 25 multiple-choice test questions covered the Comprehension, Application and Analysis levels of Bloom Taxonomy. From the 90 initial test items in the instrument, the researchers selected 30 after careful item analysis.

Two qualified senior secondary school Biology teachers and two graduate students in educational evaluation from OOU validated the instrument. The experts objectively critique the test items such that their suggestions shaped the final copy. Later, the test was administered on 30 students of a school that was not part of the study but shared comparable characteristics with those selected. The test-retest reliability method yielded a coefficient of 0.70

The researchers sought approval from the State Ministry of Education to conduct the study in the selected schools. The Principals and Biology teachers, as well as the students of the two schools, were then contacted. The visit was to seek the support of the staff and to request the consent of the students. The students agreed to participate in the study when assured that the researchers would not only mask their identities but would conduct the experiment during the school hours. The study lasted for six weeks with the first week used for training and pretesting. The implementation of the treatment was from the second week to the fifth week (2nd to 5th week). Before the treatment, there was training for the teacher in the school designated for the experiment on hands-on learning strategy. Similarly, an instructional guide was given to the teacher in the school assigned as the control group with no training. Subsequently, a 30-minute test was conducted using the BATS in the experimental and the control groups in separate days. The scores from these tests served as the pre-test scores (covariates). As stated earlier, the implementation of the treatments commenced in the second week in both groups. The teacher/researchers prepared the materials for the hands-on and then distributed paper as activity sheets to indicate the activities the students were to follow for effective learning of the topics. The students then learned through hands-on activities either as individuals or in small groups of three or four. The teacher/ researchers also acted as guides or facilitators when the need arose. Learning was further facilitated with videos and pictures on the topics projected on the wall through smartphones. De- 
pending on the contents, students under the guidance of the teachers, also navigated the school environment to have out-of-classroom learning activities. Students irrespective of their gender were encouraged to participate actively in the study. The female students observed to be passive during learning made active by frequent questioning of their understanding of the learning materials distributing questions across gender. Also, the teacher/researchers observed that some male students were not adhering to the dictates of the activity sheets. These students were encouraged and complied when teacher reinstated benefits of the activity sheets with them. Throughout the study, students freely discussed their challenges with either colleagues or teacher and got satisfactory responses. The researcher then gave a summary of the learning materials and then moved to the next topic. At the end of every lesson, learners had take-home assignments.

Meanwhile, there was pressure from the school to reduce the time on the hands-on activities. The urge was to ensure completion of the scheme of work in readiness for the unified/joint terminal examinations by the state government. In the control group, the teacher taught the same topics without the use of hands-on and no time constraints. The students listened to the teacher and copied notes from the whiteboard. The items in the BATS were then reshuffled and administered on the students of both experimental and control groups. The reshuffling was to prevent the students from seeing the similarity of both the pre-test and post-test.

The data collected from the pre-test and post-test data were analyzed using descriptive statistics of mean and standard deviation analysis and the inferential statistics of Analysis of covariance (ANCOVA). The ANCOVA was chosen due to the presence of pretest scores which served as covariates to determine the effects of strategy on students' achievement in Biology. The hypotheses formulated were tested at 0.05 level of significance.

\section{RESULT AND DISCUSSION}

This study sets out to examine the effect of hands-on learning strategy on students' achievement in Biology. The reports from the data analysis are presented in this section. The results are in the form of descriptive statistics of the study respondents and inferential statistics for the testing of hypotheses formulated for the research work.
Table 1. Descriptive Statistics of Respondents

\begin{tabular}{lllll}
\hline Group & Gender & N & Mean & Std. Deviation \\
\hline \multirow{4}{*}{ Control } & Male & 11 & 12.55 & 3.236 \\
& Female & 13 & 11.31 & 3.276 \\
& Total & 24 & 11.88 & 3.248 \\
& Male & 13 & 9.00 & 3.786 \\
\multirow{5}{*}{ Experimental Female } & 21 & 8.43 & 3.043 \\
& Total & 34 & 8.65 & 3.302 \\
\multirow{5}{*}{ Total } & Male & 24 & 10.63 & 3.910 \\
& Female & 34 & 9.53 & 3.395 \\
& Total & 58 & 9.98 & 3.625 \\
\hline
\end{tabular}

From Table 1, it is evident that 24 males in the study recorded post-test mean achievement score of 10.63 and standard deviation of 3.910 whereas 34 females recorded post-test mean achievement score of 9.53 and a standard deviation of 3.395. By strategy, 11 male students in the control group had post-test mean achievement score of 12.55 and a standard deviation of 3.236 while 13 females recorded post-test mean achievement score of 11.31 and a standard deviation of 3.786. Similarly, 13 males in the experimental group obtained post-test mean achievement score of 9.00 and a standard deviation of 3.786. The 21 females had post-test mean achievement score of 8.43 and a standard deviation of 3.043. It is also evident from the table that the mean difference in achievement by gender in the control group was $1.24(12.55-11.31)$ although that of the experimental group was 0.57 (9.00-8.43). This suggests that the gender performance gap is smaller in the group exposed to the hands-on strategy than those taught using the conventional method.

\section{Testing of hypotheses on the effectiveness of hands-on learning strategy}

The results from the testing of hypotheses formulated for this study are presented in this section. The analyses were conducted using Analysis of Covariance and pairwise comparisons of effects of the strategy and gender on the students' achievement in Biology.

$\mathrm{H}_{0} 1$ : There is no significant difference in the effect of Hands-on learning strategy on students' academic achievement in Biology

The result in Table 2 shows a significant difference in the effect of strategy $\left(F_{(1,53)}=8.595\right.$, $p=0.05$ ). This implies that the mean achievement scores of students in the post-test after exposure to hands-on learning strategy and conventional method varied significantly. Hence, the null hypothesis which states that there is no significant 
Table 2. Summary of Analysis of Covariance of students' achievement scores by strategy and gender

\begin{tabular}{lccccc}
\hline Source & Type III Sum of Squares & Df & Mean Square & F & Sig. \\
\hline Corrected Model & 319.665 & 4 & 79.916 & 9.866 & .000 \\
Intercept & 173.262 & 1 & 173.262 & 21.390 & .000 \\
Pretest & 161.322 & 1 & 161.322 & 19.915 & .000 \\
Strategy & 69.621 & 1 & 69.621 & 8.595 & .005 \\
Gender & 7.935 & 1 & 7.935 & .980 & .327 \\
Strategy * Gender & 1.621 & 1 & 1.621 & .200 & .656 \\
Error & 429.318 & 53 & 8.100 & & \\
Total & 6529.000 & 58 & & & \\
Corrected Total & 748.983 & 57 & & & \\
R Squared $=0.427$, Adjusted R Squared $=0.384$ & & & & \\
\hline
\end{tabular}

difference in the effect of Hands-on learning strategy on students' academic achievement in Biology is rejected. The pairwise comparison of the effect of strategy (hands-on and conventional method) on students' academic achievement in Biology is presented in Table 3.

Table 3. Pairwise comparison of the effect produced across strategy

\begin{tabular}{lcccc}
\hline $\begin{array}{l}\text { Teaching } \\
\text { Strategy }\end{array}$ & Mean & $\begin{array}{c}\text { Mean } \\
\text { Difference }\end{array}$ & $\begin{array}{c}\text { Std. } \\
\text { Error }\end{array}$ & Sig. \\
\hline $\begin{array}{l}\text { Conven- } \\
\text { tional }\end{array}$ & 11.396 & & 0.595 & \\
$\begin{array}{l}\text { Method } \\
\text { Hands- }\end{array}$ & & $2.329^{*}$ & & $0.005^{*}$ \\
$\begin{array}{l}\text { On } \\
\text { Learning }\end{array}$ & 9.067 & & 0.508 & \\
\hline
\end{tabular}

Covariates appearing in the model are evaluated at the following values: covariates $=10.03$.

The results in Table 3 reveal that students in the control group recorded the higher adjusted post-test mean achievement score, mean = 11.396 , S.E. $=0.596$ compared to the students in Hands-on group with adjusted post-test mean achievement score of 9.067 and standard error of 0.508 .

$\mathrm{H}_{0}$ 2: There is no significant difference in the effect of gender on students' academic achievement in Biology.

The results of the analysis of covariance in table 2 show no significant difference in the effect of gender on students' achievement in Biology ( $F$ $\left.{ }_{(1,53)}=0.980, \mathrm{p}>0.05\right)$. This result implies that the mean achievement scores of male and female students in post-test did not vary significantly. Hence, the null hypothesis stating that there is no significant difference in the effect of gender on students' academic achievement in Biology is retained.

The pairwise comparison of the effect of the gender on students' achievement in Biology is shown in Table 4.

Table 4. Pairwise comparison of the effect produced across the gender

\begin{tabular}{lllll}
\hline Gender & Mean & $\begin{array}{l}\text { Mean } \\
\text { difference }\end{array}$ & $\begin{array}{l}\text { Std. } \\
\text { Error }\end{array}$ & Sig. \\
\hline Male & 10.613 & 0.762 & 0.584 & 0.327 \\
Female & 9.850 & & 0.502 & \\
\hline
\end{tabular}

Covariates appearing in the model are evaluated at the following values: covariates $=10.03$

The evidence in Table 4 reveals that male students recorded the higher adjusted post-test mean achievement score, mean $=10.613$, S.E. $=$ 0.584 compared to the female students with adjusted post-test mean achievement score of 9.850 and standard error of 0.502 .

$\mathrm{H}_{0} 3$ : There is no significant interaction effect of strategy and gender on students' academic achievement in Biology.

The results of the 2-way interaction effect in Table 3 show non-significant interaction effect of the strategy (hands-on and conventional method) and gender on students' achievement in Biology $\left(\mathrm{F}_{(1,53)}=0.481, \mathrm{p}>0.05\right)$. This result implies that the effect of strategy (Hands-on and conventional method) on students' academic achievement in Biology between males and females did not vary significantly. Hence, the null hypothesis which states that there is no significant interaction effect of the strategy and gender on students' academic achievement in Biology is retained. The Figure 1 illustrates the gender achievement gap by strategy. 


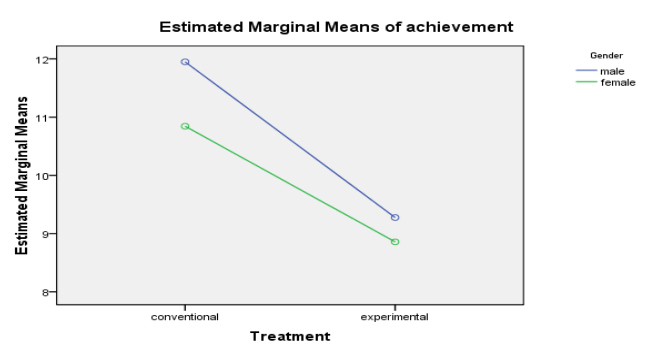

Figure 1. Gender performance gap across strategy

Figure 1 demonstrates that the gender achievement gap in both the experimental and control groups. The gap was large in the control group compared to the achievement gap in the experimental group.

The study investigated the effect of handson learning strategy on students' academic achievement in senior secondary school Biology. It also sought to find out if the strategy is capable of bridging the gender performance gap in the subject. The result of this study indicated a significant difference in the effect of strategy (hands-on and conventional method) on students' achievement in senior secondary school Biology. This means that mean achievement scores in the post-test of students exposed to the hands-on learning strategy and conventional method differed significantly. Students exposed to the conventional method of teaching recorded higher post-test mean achievement score in Biology than those exposed to the hands-on learning strategy. This finding is surprising because several studies (e.g. Ibrahim, 2020; Odewumi et al., 2020) have reported the effectiveness of the strategy. However, this result may be due to the fact students are not used to doing practical work along with every topic in Biology. So, they might need a lot of time and energy before getting used to the practice. Enebechi in Oladimeji and Adebisi (2020) observed that Biology teachers do not include practical in every topic taught but would rather wait till when instructions on specimens for practical examinations are collected from examinations' bodies. Additionally, practical activities required time which was limited due to the need to exhaust the syllabus in readiness for joint terminal examinations to be conducted by the Ogun State government. This rush might have hindered deeper learning because there was no time for practice and probably reinforcement of the contents learned. Ahmed, Dykowski, Tooley, Helland and Barremka (2017) affirmed that lack of reinforcement during the later phases of learn- ing could jeopardise learning effectiveness. This finding disagrees with Odewumi et al. (2020) which reported that students taught with plastic relief sculpture (PRS), a form of hands-on strategy performed significantly better than those exposed with the conventional method of teaching. It is also contrary to the study of Oladimeji and Adebisi (2020) that indicated that the natural and synthetic specimens improved learning of students in Biology.

This study established no significant difference in the effect of gender on students' achievement in Biology. This indicates that the mean achievement scores of male and female in post-test did not differ significantly. The likely reason for this finding may be the level of attention given to both males and females during the teaching-learning process. The active involvement of all students irrespective of their gender might have deepened their understanding of the topics. There is a tendency that this led to an almost equal improvement in their achievement. In the same manner, the learning contents might have aroused learners' curiosity and interest and propelled them to learn. This finding is in line with Odewumi et al. (2020) which established no statistically significant difference in the mean performance of male and female students when taught with plastic relief sculpture (PRS). This is similar to the finding of Ibrahim (2020) that no significant difference existed in the mean performance of males and females after exposure to the guided inquiry strategy. Further, this study found that male students performed better than their female counterparts. Unsurprisingly, the societal perception is that science is a maledominated discipline. Female students seemed to express phobia for the learning of science subjects which caused disparity in the proportion of males and females found in science disciplines (Jegede \& Olu-Ajayi, 2017). This finding corroborates the report of OECD (2015) that girls tend to underachieve compared to boys in science subjects but disagrees with that of Adolphus (2020) which found that majority of the girls in his study performed better than their male counterparts in science generally.

Another finding was that no significant interaction effect existed between the strategy and gender on students' academic achievement in Biology. This outcome implies that the mean scores of male and female students in the experimental and the control groups did not vary significantly. Meanwhile, a graphical illustration revealed that the gender achievement gap reduced in the group exposed to hands-on learning strategy compared 
to those in group taught with the conventional method. The plausible reason for this result is that the teachers ensured that all students participated actively in the learning process. The teacher distributed the questions to all students regardless of their gender. The male students were also advised to follow the dictates of the activity sheets for learning. There is a likelihood that these efforts helped them to learn gainfully. This finding is in concert with Odewumi et al. (2020); Ibrahim (2020) whose reports showed that there existed no significant difference in the mean performance of males and females after exposure to their respective hands-on strategies.

\section{CONCLUSION}

The study investigated the effect of handson learning strategy in enhancing the students' academic achievement in senior secondary school Biology and also determined whether the strategy could close the gender performance gap in the subject. The study concluded that hands-on learning strategy is not effective in enhancing students' academic achievement in senior secondary school Biology. It also concluded that students need adequate time for the hands-on strategy to be effective for learning Biology. This study, also, argues that Biology teachers need to engage students with practical work all along to give them the necessary experience to excel in learning with hands-on strategy. The study confirmed that there was no significant interaction effect of the strategy and gender on students' academic achievement in Biology. Yet, hands-on learning strategy is effective in reducing the gender achievement gap in Biology.

The study, based on its findings, recommended that school authorities should allocate adequate time for practical/hands-on activities in Biology learning. Teachers should also be trained on the incorporation of hands-on activities into the teaching Biology within the limited time. Series of seminars should be put in place to educate the students on the importance of handson activities to learning Biology for scientific development. Teachers also need training on how to use the hands-on learning strategy either in isolation or by enriching the conventional method of teaching with it.

The study sample size was presumed to be adequate based on the power analysis using $\mathrm{G}^{*}$ Power calculator. However, it is suggested that further studies should be conducted with larger sample size. Also, a mixed-methods study is suggested where students can share their experiences after exposure to the hands-on strategy.

\section{REFERENCES}

Adolphus, T. (2020). Gender and science enrolment and attainment trends in Scotland. European Journal of Education Studies, 6(10), 184-206.

Ahmed, M., Dykowski, S., Tooley, T., Helland, T. \& Barremkala, M. (2017). Influence of learning paradigms on the retention of anatomical knowledge in medical students. Federation of American Societies for Experimental Biology (FASEB) Journal, 31(1).

Aji, C., \& Khan, M. (2019). The impact of active learning on students' academic performance. Open Journal of Science, 7, 204-211.

Bertocchi, G., \& Bozzano, M. (2019). Gender gap in education: Discussion paper series. Retrieved from http://ftp.iza.org/dp12724.pdf

Borgonovi, F., \& Greiff, S. (2020). Societal level gender inequalities amplify gender gaps in problems solving more than academic disciplines. Intelligence, 79(2020), 1014422.

BouJaoude, S. (2011). Modern development in science education. Encyclopedia of Life Support Systems (EOLSS). Retrieved from http://citeseerx.ist. psu.edu/viewdoc/download?doi=10.1.1.641.2 40\&rep=rep1\&type $=$ pdf

Cooper, G., \& Berry, A. (2020). Demographic predictor of senior secondary participation in Biology, Physics, Chemistry and earth/space science: Students' access to cultural, social and science capital. International Journal of Science Education, 42(1), 151-166.

Faul, F., Erdfelder, E., Buchner, A., \& Lang, A.G. (2009). Statistical power analyses using $\mathrm{G}^{*}$ Power 3.1: Tests for correlation and regression analyses. Behavior Research Methods, 41(4), 1149-1160.

Federal Republic of Nigeria. (2014). National policy on education. Nigerian Educational Research and Development Council (NERDC) Press.

Filgona, J., Sababa, L. K., \& Filgona, J. (2016). Effect of hands-on learning strategies in senior secondary school students' academic achievement in topographical map studies in Ganye Educational Zone, Adamawa State, Nigeria. International Journal of Social Sciences and Humanities Research, 4(3), 276-287.

Ibrahim A. (2020) Guided Inquiry Strategy as Panacea for Students Poor Academic Performance in Biology for Sustainable Development. In: AlMasri A., Al-Assaf Y. (eds) Sustainable Development and Social Responsibility-Volume 2. Advances in Science, Technology \& Innovation (IEREK Interdisciplinary Series for Sustainable Development). Springer, Cham.

Jegede, S. A., \& Olu-Ajayi, F. E. (2017). Effects of mentoring and gender on the achievement of low performing students in Biology. International Journal of Education and Practice, 5(7), 104-109.

Matawali, A., Bakri, S. N. S., Jumat, N. R., Ismail, I. 
H., Arshad, S. E., \& Din, W. A. (2019). The preliminary study on inverted problem-based learning in biology among science foundation students. International Journal of Evaluation and Research in Education (IJERE), 8(4), 713-718.

Mwanda, G., Odundo, P., \& Midigo, R. (2017). Towards adoption of constructivist instructional approach in learning biology in secondary school students in Kenya: Addressing learner attitude. International Journal of Secondary Education, 5(1), 1-11.

Odewumi, M. O., Akintola, D. A., \& Bello, I. (2020). Plastic relief sculpture: Improving Nigerian students' performance in practical Biology. (JPBI) Jurnal Pendidikan Biologi Indonesia, 6(1), 101-106.

Ogunkola, B. J., \& Bilesanmi-Awoderu, J. B. (2012). Effective laboratory-based and lecture methods on students' achievement in Biology. African Journal of Education 5 (2), 247-260.

Okoye, P. O. (2016). Influence of gender and cognitive styles on students' achievement in Biology. International Journal of Science and Technology (STECH), 5(1), 59-65.

Oladimeji, O. I., \& Adebisi, T. A. (2020). Effect of synthetic and natural specimen use on process skills and application in secondary school Biology practical in Ekiti State, Nigeria. African Journal of Teacher Education, 9(2020), 120-139.

Ong'amo, B. L., Ondigi, S. R., \& Omariba, A. (2017). Effect of utilization of Biology teaching and learning resources on students' academic performance in senior secondary schools in Siaya District-Kenya. International Journal of Education and Research, 5(1), 253-272.

Organization for Economic Cooperation and Development. (2015). What lies behind gender inequality in education? PISA in focus. Retrieved from https://www.oecd-ilibrary.org/ docserver $/ 5$ js 4 xffhhc30-en.pdf?expires $=15794$ 77190\&id $=$ id \&accname $=$ guest $\&$ checksum $=3$ A0EB442FA69ED02C4EB51C98333365C

Roberts, C., M. (2010). The dissertation journey: A practical and comprehensive guide to planning, writing, and defending your dissertation (Second). United States of America: SAGE Publications Inc. Retrieved from https://www.amazon.com/ Dissertation-Journey-Practical-Comprehensive-Defending/dp/1412977983

Rosa, W. (Ed.). (2017). Transforming our world: The 2030 agenda for sustainable development. In $a$ new era in global health. New York, NY: Springer Publishing Company.

Sadi, O., \& Cakiroglu, J. (2011). Effects of hands-on activity enriched instructions on students' achievement and attitudes towards science. Journal of Baltic Science Education, 10(2). 87-97.

Shana, Z., \& Abulibdeh, E. S. (2020). Science practical work and its impact on high students' academic achievement. Journal of Technology and Science Education, 10(2), 199-215.

Sukmawati, F., Setyosari, P., Sulton, S., \& Purnomo, P. (2019). The Effect of Project-based Collaborative Learning and Social Skills on Learning Outcomes in Biology Learning. Journal for the Education of Gifted Young Scientists, 7(4), 13251344.

Taylor, A. (2019). The Impact of Inquiry-Based Science on Learning Outcomes and Language Development (Master of Arts Degree). California State University, San Marcos.

United Nations Children's Fund. (2011). Promoting Gender Equality: An Equity-focused approach to programming. Retrieved from https://www. unicef.org/gender/files/Overarching_2Pager_ Web.pdf

Wai, H. O., \& Khine, S. S. (2020). An investigation into the difficulties of students in learning Biology. J. Myanmar Acad. Arts Sci., 18(9), 183-197.

West Africa Examination Council Chief Examiners' Report (2014). General Comment, Weakness/ Remedies and Candidate's Strength. Retrieved from https://waeconline.org.ng/e-learning/ Biology/Bio223mw.html

West Africa Examination Council Chief Examiners' Report (2015). General Comment, Weakness/ Remedies and Candidate's Strength. Retrieved from https://waeconline.org.ng/e-learning/ Biology/Bio224mw.html

West Africa Examination Council Chief Examiners' Report (2016). General Comment, Weakness/ Remedies and Candidate's Strength. Retrieved from https://waeconline.org.ng/e-learning/ Biology/Bio225mw.html

West Africa Examination Council Chief Examiners' Report (2017). General Comment, Weakness/Remedies and Strength. Retrieved from https://waeconline.org.ng/e-learning/Biology/Bio226mw.html

West Africa Examination Council Chief Examiners' Report (2018). General Comment, Weakness/Remedies and Strength. Retrieved from https://waeconline.org.ng/e-learning/Biology/Bio227mw.html

Wibowo, Y. G., \& Sadikin, A. (2019). Biology in the 21st-century: Transformation in biology science and education in supporting the sustainable development goals. JPBI (Jurnal Pendidikan Biologi Indonesia), 5(2), 285-296.

Woodley, E. (2009). Practical work in school science - why is it important? SSR December 2009, 91(335), 49-51.

Ziff, B. (n.d). Developing strategies that encourage hands-on learning. Retrieved from http:// www.calstatela.edu/sites/default/files/centers/spedintern/hints09DevelopingHandsOn. pdf 